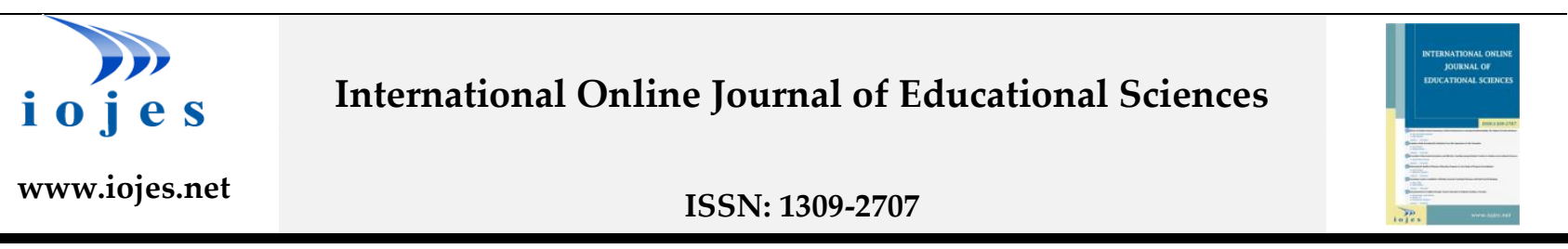

\title{
Analysis of the General Tendencies of Graduate Studies on Children's Rights Issues in Social Studies Education in Turkey
}

\section{Research Article}

\section{Kenan BAS ${ }^{1}$}

${ }^{1}$ Ağrı İbrahim Çeçen University, Patnos School of Social Services, Department of Social Services, A $\breve{g} r$, Turkey, ORCID: 0000-0003-4253-2323

To cite this article: Bas, K. (2021). Analysis of the general tendencies of graduate studies on children's rights issues in social studies education in Turkey, International Online Journal of Educational Sciences, 13(1), 86-103.

\begin{tabular}{ll} 
ARTICLE INFO & ABSTRACT \\
\hline Article History: & $\begin{array}{l}\text { This study was carried out to analyze the work carried out in the context of children's rights from } \\
\text { various aspects in the field of social studies education in Turkey and determine the intrinsic research } \\
\text { trends. The study was designed in accordance with the qualitative research approach. The document } \\
\text { analysis technique was used in order to obtain the study data. In line with this specific purpose, a } \\
\text { total of } 8 \text { graduate dissertations determined by the criterion sampling method were examined in the } \\
\text { study. The analysis of the study data was carried out with the "Descriptive Analysis" technique. As } \\
\text { a result of the study, in addition to the publication year of the dissertations and the gender of the } \\
\text { authors, findings related to the university - institute - dissertation type, themes, research method, } \\
\text { data collection tools and the results obtained in terms of the results regarding the dissertation were } \\
\text { included. As a result of the study, based on these findings, relevant concepts and suggestions were } \\
\text { developed in the context of the relevant subject for the researchers who would conduct studies on } \\
\text { this subject. }\end{array}$ \\
& $\begin{array}{l}\text { Keywords: } \\
\text { Child, Social Studies, Rights }\end{array}$ \\
\end{tabular}

\section{Introduction}

\section{The Concept of Child}

The concept of child has failed to become clear that is accepted by everyone and has had different meanings over time from culture to culture. The concepts of children and childhood vary according to place, time and situation (Smidt, 2006). Children are the individuals who were born of human beings, have a certain parent and have not yet matured in body and spirit, and have not yet reached the age of 18 and not come of age (Hançer, 2019, p.12). The exact equivalent of the word child is the human infant. It is referred to as "child" in English, "kind" in German, "enfant" in French, and "tıfll" in Ottoman (Polat, 1997, p.7). Every person under the age of 18 is a "child", except for national laws to accept the status of being an adult at an earlier age

${ }^{1}$ Corresponding author's address: Ağrı İbrahim Çeçen University

Telephone: +9004722159863

e-mail: kenanbas2301@gmail.com

DOI: https://doi.org/10.15345/iojes.2021.01.006 
(Moroğlu, 2003, p. 29). According to Aktürk (2006), the child can be defined as a human infant that has life span from birth to adolescence. According to Albayrak (2013), on the other hand, the child is an infinity ambassador for us among the color spectrum and a great living creature who can run the risk of walking with his little feet in the center of life. As stated by Akyüz (2013), childhood is a period in which physical, mental, spiritual and social changes are experienced very intensely and rapidly. In the definition offered by the United Nations and included in the universal documents, childhood period covers a period up to the age of 18 . According to the first article of the United Nations Convention on the Rights of the Child (UNCRC), everyone up to the age of 18 is considered a child (Hodgkin \& Newell, 1998; Flight, 2009). As Yapıc1 and Yapicı (2004) stated, "wherever there is the mention of a beauty in favor of life, there is always a trace of childhood". As Yapıc1 mentions, the child is a creature living on earth that waits to be discovered and offers unique beauties when discovered. (Hançer, 2019, p.11). Franklin (1993) states that childhood is a current expression that divides human life into childhood and adulthood.

In the $6^{\text {th }}$ article of the Turkish Penal Code numbered 5237, on the other hand, the child is defined as a person who has not yet turned the age of eighteen. The Islamic Law defines a person who has not yet reached puberty as a "child". Children are mentioned in the Labor Laws as well. According to the Child Protection Law, a child is a person "who has not turned the age of eighteen, even if s/he is an adult at an earlier age". In the $3^{\text {rd }}$ article of the Social Services and Child Protection Institution Law No. 2828, the term child "In Need of Protection" is considered as an individual whose physical, spiritual and moral development or safety is in danger, who have no mother and father or who are not known, who has been abandoned by his mother or father or both, and who has been neglected and exposed to bad situations, vulnerable to dangers and bad situations threats (Hançer, 2019 p.12-13).

\section{The Concept of Children's Rights}

There is a close relationship between the concept of right and the socio-economic development levels of societies. Societies can very well define the concept of rights at the level of their development and accordingly, various developments can be observed in societies. In other words, the changes and developments in the social and economic fields have determined the living standards and styles of children as well as adults (Kaya, 2011). Child's rights are a series of rights created for the world's children to live in prosperity and happiness, live a life free from abuse and negligence, and live their childhood only as they should (Erbay, 2010, p.167).

As Franklin (1996) states, "children's rights are a concept in which children are integrated with all the human rights fields that stem from being a human". According to Akyüz, (2000), on the other hand, children's rights are the rights of children protected by legal rules as a part of human rights in order for children to develop mentally, emotionally, socially and physically in a healthy way. In summary, children's rights are a more explicit and more specific examination of the concept of human rights. (Hançer, 2019, p. 16). The most important issue in the concept of children's rights is the protection of the best interests of the child. (Hançer, 2019, p. 17)

\section{Historical Development of Children's Rights}

The idea of protecting children and children's rights started with the awareness that people were responsible for children regardless of language, religion, race, color, nationality, religious belief and opinion (İnan, 1968). Centuries ago, children were regarded as beings whose physiological needs were only met insufficiently, and who were forced to work for hours regardless of their skinny bodies, and nothing seemed wrong with this situation. Newborns would just die from simple diseases, since they were deprived of the little attention and care they needed to be shown. In those times of humanity, the life span of the majority of children was very short; they passed away painfully due to poverty and deprived of love, care, and attention. Children were attached no value at all due to the prevalent ignorance in the society. This state of ignorance 
resulted in the death of the children. Moreover, vulnerable children were the first to be affected by war, famine, and poverty (Müftü, 2013).

Until the time of Aristotle, there were no moral or legal restrictions against the killing of children in Ancient Greece. At the same time, in Rome, on the other hand, fathers had unlimited rights over their children and their sovereignty over their children was indisputable. During this period, a father could punish his child as he wished, buy and sell, cripple or even kill him (Yörükoğlu, 1992). In the Mediaeval Ages, it was not possible to talk about the perception of childhood as accepted in its current form today. Generally, the idea that the children who did not have any social status; who were regarded as neglected and unwelcome individuals, were believed to be evil from birth due to the influence of Christianity was dominant. Nevertheless, there was no period called "childhood" in this period anyway. Children who were accepted as babies until the age of 6-7 did not have their own clothes, food, games and toys. At this age, children were regarded as babies up to the age of 7 , and as "petite adults" from the age of 7 after infancy.

It is clearly observed that there was no the concept of childhood here. Children at this age entered directly into the adult world, and as a result of this perception, children would try to act like adults (TrawickSmith, 2014). In the Medieval Ages when the idea of possession of property and slavery was widespread, a child was a being without rights, substituted for an item or possession. The children who were punished severely as a result of severe disciplinary rules and violation of these rules did not live in suitable shelters; they lived together with slave children and animals (Doğan 2000, p. 155). With the spread of Christianity, behaviors and attitudes such as helping out with people who were in trouble in social life and offering a helping hand to them started to be emphasized in the society. Consequently, women and children were considered as individuals who were in need of protection, and they were observed and helped with a positive approach (Flight, 2013). In the Arab communities before Islam, on the other hand, the father had unlimited authority over the children. Girls' rights were worse than boys. The father could sell his daughters to anyone he wished or just kill them. However, after the acceptance of Islam in the Arabs, these rights of the father on children were abolished by the Quran. Islam is a religion of tolerance and is more tolerant of children and their rights than any other religion. For example, Islam advised orphans to be behaved like brothers and not to lay hands on their property (Çelik, 2005). The Turkish society, which also adopted the belief of Islam, treated children positively different and kept them different from adults in terms of their needs, thoughts, arts and games. However, they could not refrain from preparing them for the real life; in a way, they prepared them for the adult life.

The ancient Turkish communities that lived a nomadic life, tried to prepare children for the natural conditions, and for wars, weapon training and hunting, as they were constantly in search of natural conditions and sovereignty. In certain ages, certain actions were expected to be performed by children; that is, certain responsibilities were granted to children. Children could not gain a valuable place in the society without acting as a real hero and doing the things in a real sense that adults could achieve (Çetinkaya, 1998. p.4). The very first legal regulations on children's rights were made for the working children in England. With the development of mining industry, the shortage of cheap labor was overcome by employing the children. However, the children were oppressed under difficult working conditions. For this reason, a law passed by the British Parliament in 1831 prohibited children and young people aged 9-21 from working at nights (Kaya, 2011).

The first realistic steps towards the protection of children or their rights, on the other hand, were taken in the Geneva Declaration of Children's Rights in 1924. This declaration led to new steps to be taken in the international arena to protect children's rights. After this declaration, some national and international declarations and conventions such as the Turkish Declaration of the Rights of the Child and the United Nations Convention on the Rights of the Child were published. Among these studies, the most comprehensive and 
internationally most supported was the United Nations Convention on the Rights of the Child. With this convention signed by all states that were members of the United Nations, the protection of children's rights was guaranteed by law. (Taşkın, 2019, p. 13).

\section{History of Children's Rights in Turkey}

Mustafa Kemal Ataturk, the president of newly founded Republic of Turkey approved the five-articled declaration of the rights of the child on children's rights to survival, development, protection and participation in 1931 (İnan, 1970; Doğan, 2000; Moroğlu, 2003; Polat, 2015). Subsequently, the Child Protection Agency was established in 1935. Mustafa Kemal Atatürk accepted and declared the date of April 23, the opening of the Parliament, as the holiday of Turkish children. After this festive holiday, with the proclamation of 1979 as the year World's Children by the UN, Turkey adopted April 23 as a gift to all the children of the world (Uçuş, 2013).

In order to raise awareness of children's rights in societies, 1979 was proclaimed as the International Year of the Child by the UN. As a result of long-term efforts, 20 November 1989 was adopted at the tenth anniversary of the International Year of the Child and at the thirtieth anniversary of the 1959 UNCRC. The convention, which was opened for signature on January 26, 1990, was approved by 61 states on the same day and when it reached the required number, it became an international law and entered into force on September 2, 1990. On September 14 the same year, Turkey also signed the convention and was adopted by the Parliament on December 9, 1994, and entered into force upon its publication in the Official Gazette on January 27, 1995.

Except for the USA and Somalia, 193 countries ratified the Convention (Cited in Aral and Gürsoy, 2001, Kalender, 2018, p.24). The first international activity for the protection of children in which our country participated were the $1^{\text {st }}$ Balkan in1936 and $2^{\text {nd }}$ Balkan in 1938 Congresses. Even though participation was limited to the Balkan countries, it was significant in that it led the international studies on children's rights (Moroğlu, 2003, p.31; Akyüz, 2018, p.43).

\section{Social Studies Education and Children's Rights}

The Social Studies course in primary schools aims to raise good and responsible citizens and enables students to adapt to the daily life. According to Tezgel (2008), "social studies is a course that enables students to adapt to society as citizens who have adopted democratic values and equip the students with the knowledge and experience they have acquired on this subject". The social studies course aims to directly provide children from a broad social spectrum with basic knowledge and skills such as human rights and children's rights related to citizenship education. Thanks to this program, students try to learn the historical foundations of both our country and the world, and learn about the lives of important people who have contributed to the development of humanity, democratic forms of governance and their functioning and the values and beliefs available within the rich cultural mosaic of our country.Therefore, citizenship awareness of the students begins to develop. While human rights education is given in the Social Studies course, in line with the principle of near and far, it is a course that tries to help students to learn about their rights first and then to inform the students correctly about the rights and freedoms that other citizens have in society.

From past to present, the subject of human rights has always been included in the social studies curriculum, which includes many other disciplines. Of course, the issues expressed regarding human rights are also valid for children's rights. Furthermore, it is commonly known that the statements about children's rights are more common in Social Studies Curriculum compared to the other programs. The result of the study conducted by Merey (2012) already supports this finding. Therefore, social studies course is a very suitable course for children to learn about their rights. In this context, it is possible to claim that the Social Studies course fulfills an important mission. 


\section{Purpose of the Study}

The purpose of this study is to examine from various aspects the postgraduate dissertations prepared on the subject of Children's rights in the field of Social Studies education and reveal the tendency of the studies in question. In line with the purpose of the study, answers were sought for the following questions.

1. What is the distribution of these graduate dissertations by the years they were published?

2. What is the distribution of these graduate dissertations by the gender of their authors?

3. What is the distribution of these graduate dissertations by the university / institute / dissertation type?

4. What is the distribution of these graduate dissertations by the themes?

5. What is the distribution of these graduate dissertations by the methods used?

6. What is the distribution of these graduate dissertations by the data collection tools used?

7. What is the distribution of these graduate dissertations by the results obtained?

\section{Method}

\section{Study Pattern}

In the present study, qualitative research methods and techniques were used. According to Yildirım and Şimşek (2013), qualitative research is a research in which qualitative data collection methods such as observation, interview and document analysis are used, and a qualitative process is followed to reveal the perceptions and events in a realistic and holistic manner in the natural environment. Qualitative research allows the current situation to be studied in depth (Karasar, 2012). In this study, document analysis technique, one of the qualitative research methods, was used. Document analysis is defined as a method of extracting information from the documents such as printed and other materials for research, personal documents, and visual materials for daily life (Merriam, 2013).

\section{Study Group}

The study group is constituted of 1 doctoral and 7 master's dissertations related to children's rights issues in the Social Studies Education in Turkey.

\section{Data Collection and Analysis}

In line with the purpose of the present study, the national dissertation center of YÖK (the council of higher education) was used. The dissertations were scanned in detail on the national dissertation page of YÖK on 14.02.2020 with the keywords "Children's rights, children's rights, children's participation rights". As a result of the scanning, a total of 122 studies consisting of Master's and Doctorate dissertations were obtained. The studies obtained as a result of the research with keywords were added to the list of studies to be analyzed in line with the purpose of the study. Out of the studies obtained, 114 postgraduate dissertations that were not conducted in the field of Social Studies Education or were not related to the subject were not included in the study. A total of 7 master's dissertations and 1 doctoral dissertation on children's rights in the field of Social Studies Education were included in the study.

A "Thesis Examination Form" suitable for the purpose of the study was developed by the researcher in order to examine the dissertations obtained. The relevant literature was used in the development of the form in question. Firstly, a draft form was created. The draft form was submitted to the opinion of two scientists (Dr. Faculty Member: 1; Assoc. Dr. 1) working in the field of assessment and evaluation. The thesis review form was eventually finalized in line with the feedback received. This form contained information about the year of the thesis, the gender of the author, the university-institute-thesis type, the subject of the study, the research 
method, the data collection tools used in the study and the results of the study. Within the scope of the study, the information about the dissertations was examined individually through the dissertation examination form prepared by the researcher.

At the outset, the researcher recorded the data of the dissertation he examined on the form created. After this stage, the accuracy of the data entered was re-examined and checked by another expert researcher. Finally, dissertations were re-examined at different time intervals (10.03.2020). At the last stage, it was decided to analyze 8 postgraduate dissertations on children's rights in the field of Social Studies Education. Descriptive analysis technique was used in the analysis of the data. The data obtained in the descriptive analysis are summarized and interpreted according to previously determined themes. The findings can be arranged according to the themes revealed by the questions of the research or they can be presented by considering the questions used in the interview process (Yıldırım \& Şimşek, 2013).

\section{Findings}

This section includes the findings obtained as a result of the study.

\section{Findings Regarding the First Sub-Problem}

What is the distribution of graduate dissertations by the years they were published?

Table 1. Distribution of graduate dissertations by the years they were published

\begin{tabular}{llll}
\hline Publication Year of the Dissertation & Author Code & Author & f \\
\hline 2011 & A1 & Fatma Torun & 1 \\
\hline 2012 & A2 & Zihni Merey & 1 \\
\hline 2014 & A3 & Ayfer Durgut & 1 \\
\hline 2018 & A4 & Maide Şila Tiftikçi & 1 \\
\hline 2019 & A5 & Atilla Taşkın & 1 \\
\hline 2019 & A6 & Gamze Hançer & 1 \\
\hline 2019 & A7 & Sevim Çavuş & 1 \\
\hline 2019 & A8 & Yunus Atik & 1 \\
\hline & & Total & 8 \\
\hline
\end{tabular}

When Table 1 is examined, it is clearly observed that the studies on Children's rights in the field of Social Studies Education generally increased after 2010. Furthermore, when evaluated as the year of publication, it is clearly seen that the studies conducted intensified especially in 2019.

\section{Findings Regarding the Second Sub-Problem}

What is the distribution of graduate dissertations by the gender of their authors?

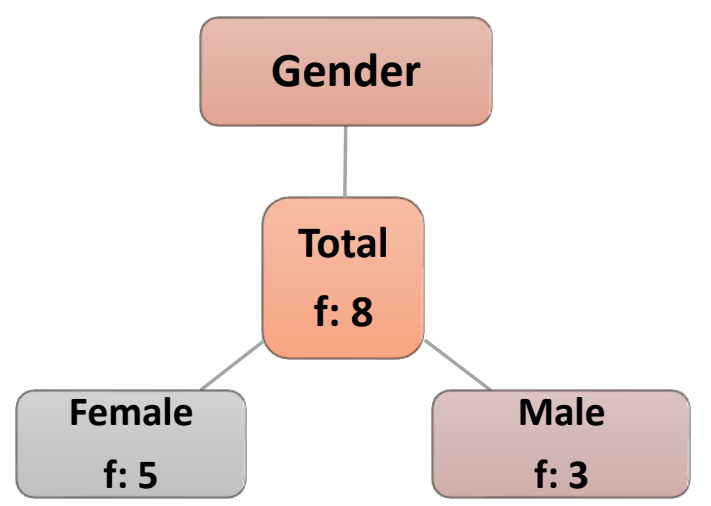

Figure 1. Distribution of Graduate Dissertations by the Gender of Authors 
When Figure 1 is examined, it is seen that there were a total of 8 studies on children's rights in the field of Social Studies education, and most of these studies were conducted by Female (f: 5) researchers.

\section{Findings Regarding the Third Sub-Problem}

What is the distribution of graduate dissertations by the university / institute / dissertation type?

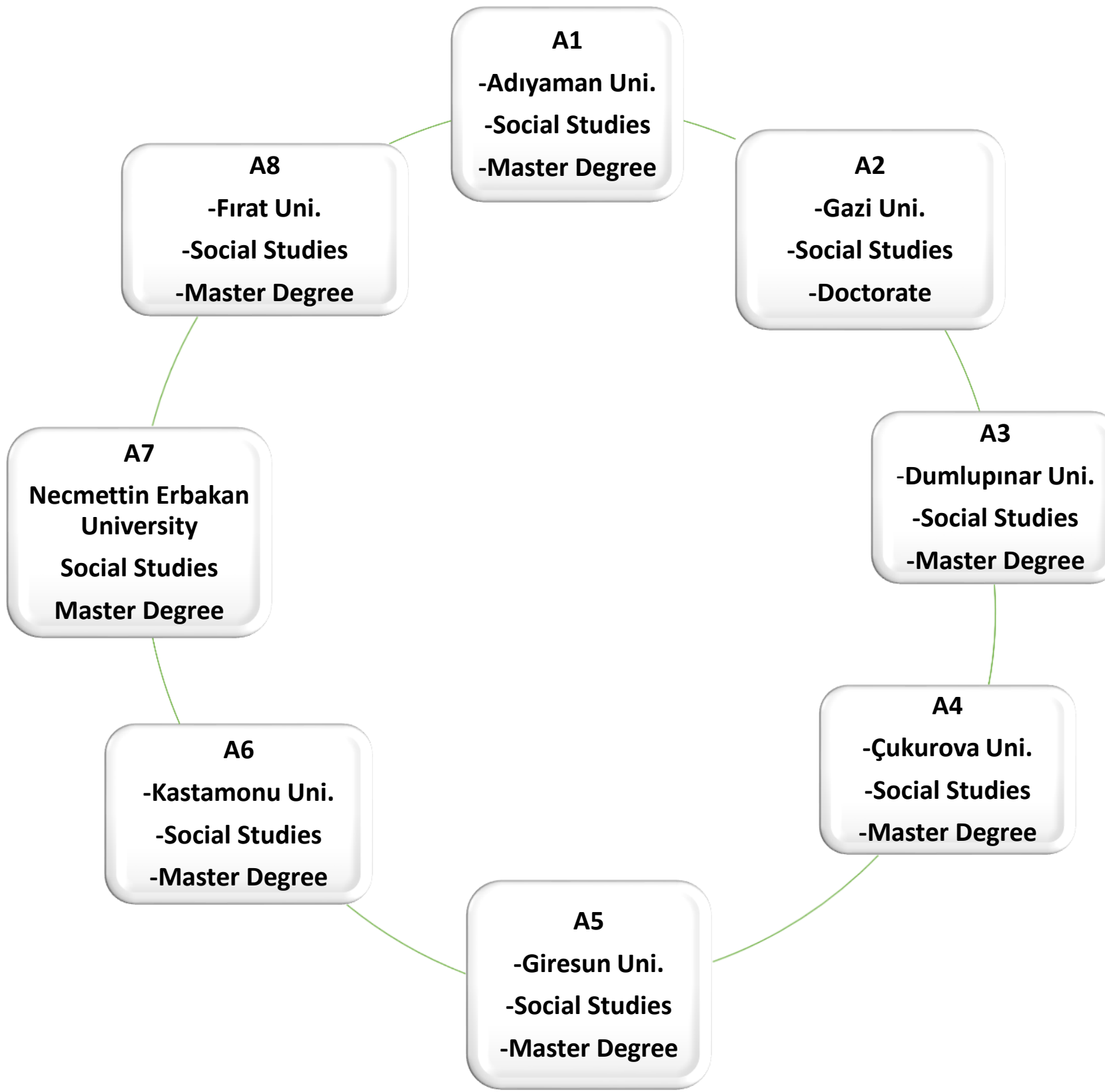

Figure 2. Distribution of Graduate Dissertations by University / Institute / Thesis Type

When we take a look at Figure 2, when the distribution of dissertations on children's rights in the field of Social Studies Education by universities is examined, it is clearly seen that the studies generally did not focus on a specific university or universities. When all things considered, it is observed that the dissertations done on the relevant subject were carried out at the universities located in almost all regions of Turkey. According to this result, it is possible to say that this subject of children's rights was among the subjects that were given priority throughout the country in graduate studies in the field of Social Studies education. 
When Figure 2 is examined, it is seen that the distribution of studies on children's rights in the field of Social Studies Education by institutes' demonstrated an even distribution. Half of the studies were carried out within the scope of Educational Sciences (f: 4) and the other half within the scope of Social Sciences (f: 4) institutes.

When Figure 2 is examined, as far as the distribution of studies on children's rights in the field of Social Studies Education by dissertation type is considered, most of the dissertations (f: 7) were at the master's degree level and one dissertation was conducted at the doctoral level.

\section{Findings Regarding the Forth Sub-Problem}

What is the distribution of graduate dissertations by the titles?

Table 2. Distribution of graduate dissertation by themes

\begin{tabular}{ll}
\hline Author & Theme \\
\hline Fatma Torun & $\begin{array}{l}\text { The Effect of Game Method in Children's rights Education on Success, Stability and } \\
\text { Attitude }\end{array}$ \\
\hline Zihni Merey & $\begin{array}{l}\text { Comparison of the Inclusion Levels of the Children's Participation Rights in the Social } \\
\text { Studies Textbooks in Turkey and the US }\end{array}$ \\
\hline Ayfer Durgut & An Analysis of the 2005 Social Studies Curriculum in Terms of Children's rights \\
\hline Maide Şila Tiftikçi & Views of Fifth Grade Social Studies Students' on Children's rights Awareness \\
\hline Atilla Taşkın & $\begin{array}{l}\text { Investigation of the Relationship Between Parental Attitudes on Children's rights and } \\
\text { the Awareness Levels of Secondary School Students }\end{array}$ \\
\hline Gamze Hançer & Views of Social Studies Pre-service teachers on Children's rights and Child Abuse \\
\hline Sevim Çavuş & $\begin{array}{l}\text { Investigation of Secondary School Students' Cognitive Structures Regarding the } \\
\text { Concept of Children's rights }\end{array}$ \\
\hline Yunus Atik & Views of Social Studies Teachers' on Children's rights \\
\hline
\end{tabular}

According to the data in Table 2, when the themes related to children's rights in the field of Social Studies Education are examined, it is seen that the researchers generally carried out studies that revealed the perceptions and thinking structures of the masses that made up the study group in the study. However, the extent to which the social studies program included the issue of children's rights appeared as another theme examined.

\section{Findings Regarding the Fifth Sub-Problem}

What is the distribution of graduate dissertations by the methods used?

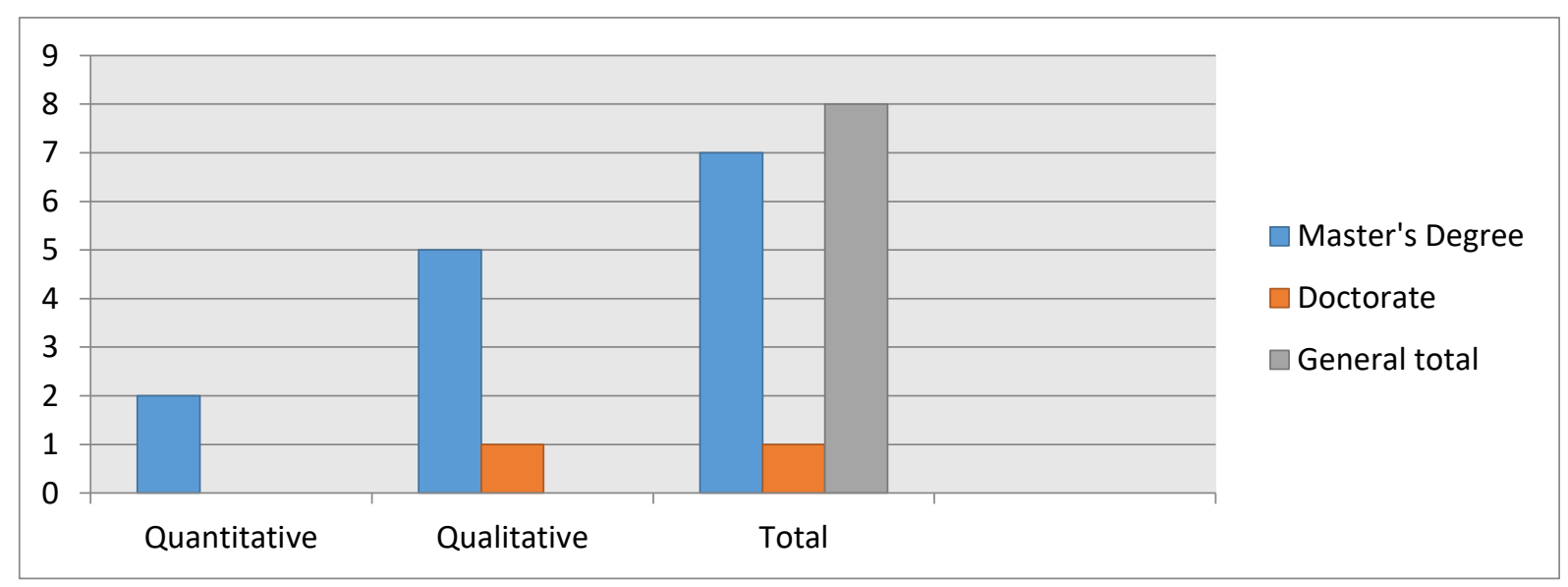

Figure 3. Distribution of Graduate Dissertations by the Methods Used

Master's Degree Doctorate General Total Quantitative Qualitative Total 
When Figure 3 is examined, it is observed that most of the studies on children's rights in the field of Social Studies education were the qualitative studies conducted the level of "Master's Degree". As seen in Figure 3, at the master's degree level (f: 5); at the doctoral level (f: 1 ) dissertations were written using the qualitative method. However, it is seen that only two studies were written using the quantitative method.

\section{Findings Regarding the Sixth Sub-Problem}

What is the distribution of graduate dissertations by the data collection tools used?

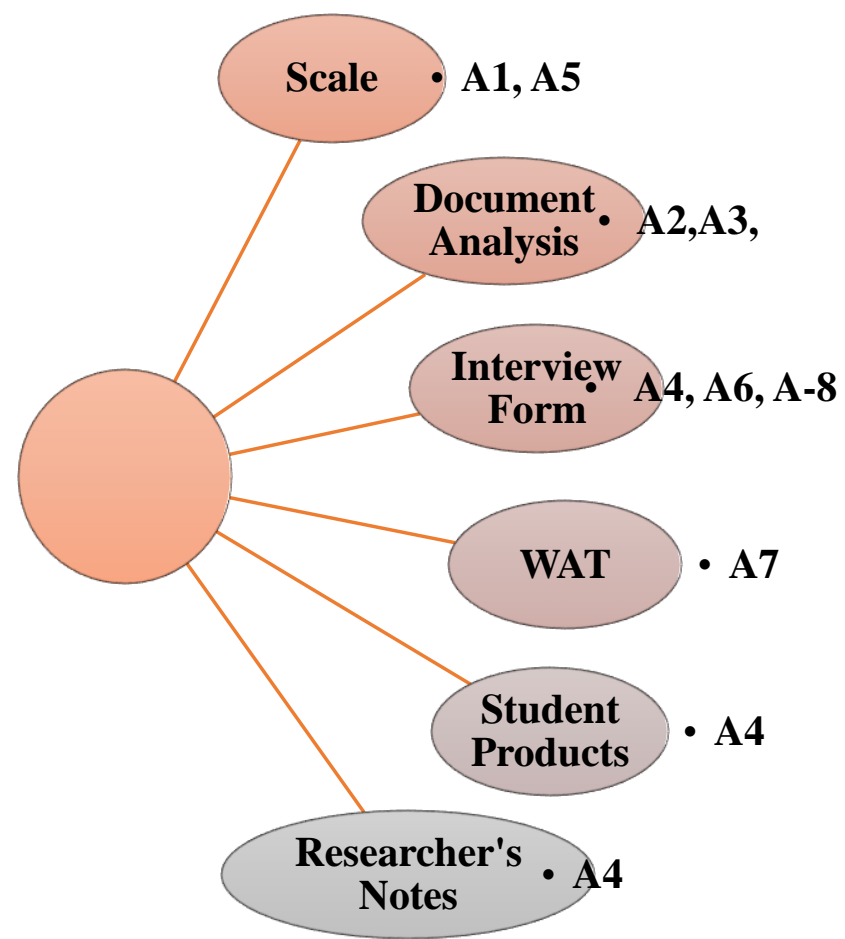

Figure 4. Distribution of Graduate Dissertations by the Data Collection Tools

When Figure 4 is examined, it is seen that in the vast majority of studies on children's rights in the field of Social Studies Education, interview forms (f: 3), scale (f: 2) and documents (Social studies textbook, Social Studies curriculum) were used as data collection tools. In addition to these, it is seen that researchers used the WAT (Word Association Test) (f: 1), Student Products (Activity Examples during the Practice) (f: 1) and Researcher's Notes (f: 1 ) as data collection tools in their studies.

\section{Findings Regarding the Seventh Sub-Problem}

What is the distribution of graduate dissertations by the results obtained?

Table 3. Distribution of the Graduate Dissertations by the Results Obtained for the Authors with the A1-A2-A3-A4 Code

Author Code Results Obtained

$>$ As a result of this experimental study, it was observed that the students' attitudes towards the subject of children's rights were higher in the experimental group when compared to the control group.

The following conclusions were obtained regarding the participation granted to children by the Child Rights Conventions (CRC) available in the Social Science textbooks used in Turkey and the US.

$>$ It was found that the frequency of participation rights of children available in the social studies textbooks in primary schools were higher in Turkey (f:1611) than the United States (f:320). 


\begin{tabular}{|c|c|c|}
\hline & $>$ & $\begin{array}{l}\text { It was concluded that the social studies textbooks in Turkey did not contain enough } \\
\text { information on children's rights to participate in the family, public policy, health } \\
\text { and judicial environment. }\end{array}$ \\
\hline & $>$ & $\begin{array}{l}\text { It was revealed that some units in the Social Studies books related to the issues about } \\
\text { children's rights in Turkey were not sufficiently internalized. }\end{array}$ \\
\hline & $>$ & $\begin{array}{l}\text { It was found that the statements about children's participation rights in Social } \\
\text { Studies textbooks in the USA were in line with the way they were defined in the } \\
\text { U.N's convention on children's rights; they were, in fact, in line with the aim of } \\
\text { raising a positive youth, which is a requirement of democratic citizenship education } \\
\text { aimed in the USA. }\end{array}$ \\
\hline \multirow{3}{*}{ A3 } & $>$ & $\begin{array}{l}\text { It was stated that the most achievements regarding the children's rights education } \\
\text { in the Social Studies curricula were in the } 4^{\text {th }} \text { grade and the least achievements were } \\
\text { in the } 6^{\text {th }} \text { grade Social Studies curricula. Similarly, it was determined that in the } \\
\text { curricula, the most achievements were related to the subject of "Individual and } \\
\text { Society" and the least achievements were related to the subject of "Culture and } \\
\text { Heritage". }\end{array}$ \\
\hline & $>$ & $\begin{array}{l}\text { It was observed that there were a total of } 174 \text { achievements in the } 4-5-6-\text { and } 7^{\text {th }} \\
\text { grade Social Studies course curricula and } 129 \text { interim discipline achievements } \\
\text { associated with it. In the curricula, it was found that the least interim discipline } \\
\text { acquisition related to children's rights was observed at the } 6^{\text {th }} \text { grade level. }\end{array}$ \\
\hline & $>$ & $\begin{array}{l}\text { The achievements gained in the Social Studies curriculum (which Turkey ratified in } \\
\text { 1990) was formed by the } 42 \text { basic items available in the CRC. Among these items, it } \\
\text { was observed that the most association was made with the item } 29 \text { (the item related } \\
\text { to the goals of education in the Social Studies curriculum). }\end{array}$ \\
\hline A4 & $>$ & $\begin{array}{l}\text { In this particular study, which attempted to determine the awareness of } 5^{\text {th }} \text { grade } \\
\text { students about children's rights through art activities, it was revealed that the } \\
\text { students felt more innovative and creative, and that the students were happy with } \\
\text { the activities. Nevertheless, it was observed that the students generated awareness } \\
\text { about gender equality and child labor, and they became aware of the rights of } \\
\text { children to live in a clean environment, development and growth. }\end{array}$ \\
\hline
\end{tabular}

According to the data in Table 3, considering the studies conducted by researchers with the codes A1A2-A3-A4 on the subject of children's rights in the field of Social Studies education, in the experimental study conducted by the researcher coded A1, it was found that the students in the experimental group had a more positive attitude towards children's rights than the control group; as a results of the A2 coded researcher's study, in general the Social Studies textbooks were examined within the scope of the research, and as a result, the issue of children's rights is not adequately covered in the textbooks; however, the children's rights issues were emphasized more in Social Studies textbooks in Turkey than those in the United States; as a result of the study of the researcher coded A3, it was found that the most achievements about children's rights in the Social Studies curriculum were obtained at the $4^{\text {th }}$ grade level and the least achievements at the $6^{\text {th }}$ grade level, and that the Social Studies curriculum was shaped by the 42 basic articles present in the child rights convention; and as a result of the study conducted by the researcher coded A4 with the $5^{\text {th }}$ grade students, it was observed that the students gained awareness of gender equality, child labor, and the children became aware of the right to live, develop and grow in a clean environment. 
Table 4. Distribution of Graduate Dissertations in Terms of Results Obtained for the Authors Coded A5-A6

\begin{tabular}{cl}
\hline Author Code & \multicolumn{1}{c}{ Results Obtained } \\
\hline & $\begin{array}{l}\text { In a quantitative study examining the relationship between parental attitudes on children's } \\
\text { rights and the level of awareness of secondary school students, the following results were } \\
\text { obtained. }\end{array}$ \\
\cline { 2 - 3 } & It was observed that while there was statistically no significant difference \\
between variables of gender, father's educational status, mother's education status, \\
number of siblings, number of siblings attending school, family income, child age, \\
parental age, parental birthplace, parental education status, parental occupation \\
status, parental marital status, there was a statistically significant difference related to \\
the variables of family (in favor of intact families) and grade level (in favor of $5^{\text {th }}$ and \\
$8^{\text {th }}$ grades).
\end{tabular}

The following results were obtained in the study conducted with Social Studies pre-service teachers.

$>$ Social Studies pre-service teachers associated the concept of children's rights with the concepts of birthright, right to life, right to protection, right to education, right to food, right to shelter, right to play, right to health, freedom of expression.

$>$ Social Studies pre-service teachers stated that teaching activities should be carried out through game activities in teaching the subject of children's rights, and that students should be made aware of children's rights through activities such as theater plays, panels, conferences, and seminars.

$>$ Social Studies pre-service teachers stated that families should be informed about children's rights.

$>$ Social Studies pre-service teachers stated that any no activity related to children's rights was held for them.

$>$ Social Studies pre-service teachers defined the concept of "abuse" as disturbing behavior. However, they associated child abuse with the concepts of "abuse of goodwill, imposed behavior, restriction of freedom and harassment". A6 knowledge and information about emotional abuse.

$>$ It was observed that Social Studies pre-service teachers did not have enough

Social Studies pre-service teachers tried to define the concept of sexual abuse with touching private areas in the body, using force, using children for sexual purposes and expressions related to rape.

$>$ Social Studies pre-service teachers defined violence as physical abuse.

$>$ Social Studies pre-service teachers explained the concept of "neglect" with the terms of ignoring and ignoring the individual.

$>$ Social Studies pre-service teachers were not insensitive to child abuse. They stated that they would receive assistance from the relevant persons and institutions (Psychological Counselor, Social Service), especially the Police, when they encountered any abuse.

$>$ It was revealed that Social Studies pre-service teachers had sufficient awareness about children's rights, however Social Studies pre-service teachers did not have enough activities and practices.

$>$ Social Studies pre-service teachers wanted to know how often child abuse occurred, what the punishments were given, what the types of abuse existed, what preventive measures were to be taken on abuse, what kind of studies were done on abuse, and to what extent the training on abuse was effective and sufficient. 
According to the data in Table 4, considering the studies of A5-A6-coded researchers on the subject of children's rights in the field of Social Studies education, as a result of the study conducted by the A5 coded researcher, it was found in the experimental study which considered the variable of "family" that the relationship between the parents' attitudes on children's rights and the level of awareness of secondary school students was in favor of the families whose mother and father were together; and according to the "class" variable, there was a significant difference in favor of the $5^{\text {th }}$ and $8^{\text {th }}$ grades.

As a result of the study conducted by the researcher coded A6 with Social Studies pre-service teachers, it was found that Social Studies pre-service teachers associated the concept of children's rights with various concepts (right to life, right to protection, right to education, right to nutrition, etc.); they stated that especially the games-based activities should be held in children's rights education and that families should be informed about this issue; that Social Studies pre-service teachers were not fully aware of the concept and types of "abuse"; and that Social Studies pre-service teachers were not insensitive to child abuse and could get help from relevant persons and institutions when necessary.

Table 5. Distribution of Graduate Dissertations in Terms of Results Obtained for A7-A8 Coded Authors

\begin{tabular}{|c|c|}
\hline Author Code & Results Obtained \\
\hline \multirow{6}{*}{ A7 } & $\begin{array}{l}\text { The following results were obtained as a result of the study examining the Cognitive Structures } \\
\text { of Secondary School Students on the Concept of Child Rights. }\end{array}$ \\
\hline & $\begin{array}{l}\text { It was observed that games and education occupied the most places in the } \\
\text { cognitive structures of secondary school students regarding children's rights. }\end{array}$ \\
\hline & $\begin{array}{l}\text { It was observed that in the cognitive structures of secondary school students, the } \\
\text { concept of freedom was followed by the concepts of the right to live, to eat and to } \\
\text { dress, respectively. }\end{array}$ \\
\hline & $\begin{array}{l}\text { It was observed that the concepts of trust-safety, participation and equality were } \\
\text { less repeated in the cognitive structures of secondary school students. }\end{array}$ \\
\hline & $\begin{array}{l}\text { It was observed that there was very little information about the right to put to } \\
\text { work and rest, the right to travel, the right to family and care in the cognitive } \\
\text { structures of secondary school students. }\end{array}$ \\
\hline & $\begin{array}{l}\text { In the cognitive structures of some secondary school students, it was observed } \\
\text { that there were some misconceptions about children's rights and that the students } \\
\text { failed to distinguish between the concepts of rights and responsibilities and, } \\
\text { accordingly, they defined some responsibilities (studying, etc.) as rights. }\end{array}$ \\
\hline \multirow{6}{*}{ A8 } & $\begin{array}{l}\text { In this study in which Social Studies teachers' views on children's rights were identified, the } \\
\text { following results were obtained. }\end{array}$ \\
\hline & $\begin{array}{l}\text { Social studies teachers believed that there were serious problems to comply with } \\
\text { the child rights convention both in the world and in Turkey. }\end{array}$ \\
\hline & $\begin{array}{l}\text { Social Studies teachers believed that there were serious shortcomings in child } \\
\text { rights convention events held, the measures taken and legal sanctions in Turkey. }\end{array}$ \\
\hline & $\begin{array}{l}\text { Social Studies teachers believed that children's rights were violated mostly } \\
\text { regarding the issues such as physical and psychological violence, sexual abuse, child } \\
\text { labor, health rights, and the right to education (seasonal workers). }\end{array}$ \\
\hline & $\begin{array}{l}\text { Social Studies teachers believed that awareness should be created especially } \\
\text { among students in child rights education. }\end{array}$ \\
\hline & $\begin{array}{l}\text { Social Studies teachers stated that the number of activities for children's rights } \\
\text { should be increased, examples from daily life given, drama method used, boards } \\
\text { containing posters and banners created in the Social Studies lessons; they stated, on } \\
\text { the other hand, that the content in the Social Studies textbooks should be enriched, } \\
\text { and the expressions and visuals about children's rights should be increased. }\end{array}$ \\
\hline
\end{tabular}


According to the data in Table 5, when we look at the studies of A7-A8-coded researchers on the subject of children's rights in the field of Social Studies education, as a result of the study of the A7 coded researcher study with secondary school students, it was observed that the concept of play was the most prominent in the cognitive structures of the students; the concepts of security, equality and participation were less expressed; the students did not know much about the concepts of rest, travel, family and right to care; additionally, it was observed that students had some conceptual inaccuracies in their cognitive structures about children's rights. As a result of the study of A8 coded researcher with the Social Studies teachers, the Social Studies teachers stated that they experienced significant problems in complying with the children's rights conventions in the world and in Turkey; there were shortcomings in activities related to the convention and law enforcement operations conducted in Turkey; the children in Turkey suffered most from physical, psychological and sexual abuse; furthermore, the children's education and health rights were violated. Additionally, Social Studies teachers stated that various activities related to the CR Convention should be carried out, examples from daily life should be given, drama method should be used in Social Studies lessons, and content of the Social Studies textbook should be enriched.

\section{Discussion, Conclusion and Recommendations}

The following results were obtained in this study in which the general tendencies in the graduate dissertations on children's rights in the field of Social Studies education in Turkey were examined.

1. Studies on children's rights in the field of Social Studies education were carried out the most in 2019 (f: 4).

2. Considering the distribution of researchers working on the subject of children's rights in the field of Social Studies education by gender, it was observed that the number of female students (f: 5) were higher than the male students (f: 3). The result of a similar study by Dündar and Hareket, (2017) overlaps with the result of the present study. This particular result may be due to the fact that women are emotionally different from men towards children or thanks to the feeling of motherhood.

3. When we examine the distribution of studies on children's rights in the field of Social Studies education by universities, it is clearly seen that studies were carried out on this subject at universities located in almost all regions of Turkey;

Considering the distribution by institutes, there was an equal distribution (Educational Sciences $\mathrm{f}: 4$, Social Sciences $\mathrm{f}: 4$ ); regarding the distribution by dissertation type, it was seen that the majority of the studies (f: 7) were conducted at the master's degree level. It was seen that the results of similar studies conducted by Kadan (2019), Dündar and Haraket (2017) and Erkan (2018) were in line with the results of the present study.

4. When we evaluate the studies on children's rights in the field of Social Studies education in terms of the method used, it was seen that the majority of the studies (f: 6) were prepared by the qualitative methods. The result of a similar study by Dündar and Hareket (2017) overlapped with the result of the present study. More emphasis might have been placed on the qualitative studies, as it was thought that the qualitative studies in comparison to quantitative studies might reveal more data in the creation of the main framework in determining the underlying causes of the problems or in finding out about children's rights in depth. It is because the sheer numbers in social problems may not give researchers sufficiently much information about the details after a certain stage.

5. In the studies on children's rights in the field of Social Studies education, it was revealed that the interview forms (f: 3), scale (f: 2) and documents (textbook, curriculum guide) were used the most as data collection tools. On the other hand, WAT (Word Association Test) (f: 1), Student Products (Examples of activities performed during the practice) (f: 1$)$ and Researcher's Notes (f: 1$)$ were among 
the other data collection tools that were used in studies, even if just a little. The results of the studies conducted by Kadan (2019), Dündar and Hareket (2017) and Erbay (2012) were similar to the results of the present study. Especially regarding the interview method, most of the researchers may have preferred this method, as they could get the opportunity to observe the body language, voice tone of the participants, and their approach to the subject more concretely, and evaluate the general attitude of the participant regarding the problem as a whole.

6. Considering the evaluation of the distribution of studies on children's rights in the field of Social Studies education based on the results obtained,

$>$ As a result of the experimental studies conducted on the subject of children's rights, it was observed that the students' attitudes towards the subject were higher in the experimental group.

> It was observed that the subject of children's rights was not emphasized much in the Social Studies textbooks in Turkey and the subject was not internalized. The result of the study conducted by Şallı (2017) supports the result of the present study.

$>$ It was revealed that the achievements related to the subject of children's rights in Social Studies textbooks were at the $4^{\text {th }}$ grade the most and at the $6^{\text {th }}$ grade the least.

$>$ It was found that the achievements in the Social Studies curriculum were formed by the 42 basic articles present in the children's rights convention and were mostly associated with 29 specific items among these items.

$>$ It was found that teaching children's rights through art activities affected the students positively in many ways (awareness, success and happiness).

$>$ In a study examining the relationship between parental attitudes and students' awareness of children's rights, on the other hand, it was found that there was a significant relationship in favor of parents who were together (unbroken family).

$>$ In a study conducted with the Social Studies pre-service teachers, they associated the concept of children's rights with the concepts of the right to life, protection, housing, nutrition, education, health and freedom of expression. In another study conducted by Kardeş, Banko, Eren, Antakyalığlu (2017) with pre-service teachers, it was found that pre-service teachers similarly associated the concept of children's rights with the same terms.

> Social Studies pre-service teachers stated that activities such as games, theater plays, drama and conferences should be held in teaching the concept of children's rights. This particular result may be related to the age level of the children, as well as due to the children's need for games, as an educational way to recognize life and learn their basic rights.

> Social Studies pre-service teachers stated that no promotional activity was held for them on children's rights. This particular result may be due to the existence of some shortcomings in the Social Studies Education Undergraduate Curriculum.

$>$ It was revealed that the Social Studies pre-service teachers defined the concept of "abuse" correctly; they associated the concept of sexual abuse with the concepts of harassment, touching private areas in the body, use of force and rape; however, it was clearly observed that the Social Studies pre-service teachers did not have enough knowledge and information about "emotional abuse". This may be due to the lack of a complementary informative study for pre-service teachers on the subject of "emotional abuse", which is one of the types of abuse, or the insufficient practice activities on the subject. 
$>$ It was found that Social Studies pre-service teachers were not insensitive to child abuse, and they could easily get help from relevant persons and institutions when they encountered any situation related to the subject.

$>$ In the study conducted with secondary school students, it was observed that the students did not have sufficient level of knowledge and information about children's rights, but they had some misconceptions about them. As the results of this study could go some way to justify this particular finding, the fact that the subject of children's rights was not sufficiently covered in the Social Studies curriculum can be regarded as the main cause of this particular result.

$>$ In the study conducted with the practicing social studies teachers, on the other hand, the teachers stated that the country experienced serious problems in terms of compliance with the children's rights convention; moreover, there were some big problems in the activities regarding the convention and the legal sanctions in Turkey. The studies conducted by Aktürk, (2006), Baysan and Kobat (2009), Koran (2015) obtained similar results to the present study.

> Social Studies teachers believed that the children in Turkey were subjected to psychologically, physical and sexual violence the most; they also thought that children were abused for the right to education and health and child labor. The results of the studies conducted by Turanl1 (2014) and Erbay (2013) reinforces the result of the present study. Especially the finding related to psychological and physical violence might be caused by the traditional structure of certain regions with low socio-economic level of the society, as well as the possibility that national and local governments might be insensitive to the mentioned problems.

$>$ Social Studies teachers stated that the number of activities related to the subject should be increased, examples from daily life given, the drama method used, posters and banners created; and they further stated that the content in the Social Studies textbooks should be enriched and the statements and visuals about children's rights should be increased. Similar results were found in the study conducted by Şallı (2017) as well. In summary, this finding can be interpreted as that the Social Studies teachers thought that concretizing the subject of children's rights would be more efficient and more beneficial in terms of permanence of information.

Based on the results, the following suggestions can be made;

$\checkmark$ More academic studies can be conducted on children's rights in the context of Social Studies.

$\checkmark$ Various informative activities and programs on children's rights can be provided to in-service social studies teachers at the undergraduate level, and to the Social Studies teachers within the scope of in-service training activities.

$\checkmark$ Necessary arrangements can be made by determining the shortcomings in the existing practices in the Social Studies curriculum.

$\checkmark$ It may be useful to review the content of Social Studies textbooks within the scope of children's rights.

$\checkmark$ Raising awareness of the Social Studies in-service teachers about "emotional abuse" may prevent the possible abuse type (emotional). 


\section{REFERENCES}

Aktürk, S. (2006). "Avrupa Birliği Sürecinde Türkiye' de Çocuk Hakları ve Güvenliği”, Yüksek Lisans Tezi, Mustafa Kemal Üniversitesi Sosyal Bilimler Enstitüsü. Hatay.

Akyüz, E. (2000). Ulusal ve Uluslararası Hukukta Çocuğun Haklarının ve Güvenliğinin Korunması, Ankara: Milli Eğitim Basımevi.

Akyüz, E. (2013). “Çocuğun Bilgi Edinme ve Zararlı Yayınlara Karşı Korunma Hakkı”, I. Türkiye Çocuk ve Medya Kongresi, Kasım, İstanbul: Çocuk Vakfı Yayınları, s.115-132.

Akyüz, E. (2018). Çocuk Hukuku. Ankara: Pegem Akademi Yay. 6. bs.

Albayrak, A. (2013). “Çocuğa Saygılı Medya Anlayışı (Psiko-Teolojik Eleştirel Yaklaşım)”, I. Türkiye Çocuk ve Medya Kongresi, Kasım, İstanbul: Çocuk Vakfı Yayınları, 199-206.

Atik, Y. (2019). Sosyal Bilgiler Öğretmenlerinin Çocuk Haklarına Görüşleri. Yüksek Lisans Tezi, Fırat Üniversitesi, Eğitim Bilimleri Enstitüsü. Elazığ.

Baysan Kobat, İ. (2009). Ulusal ve Uluslararası Hukukta Çocuk Hakları Işı̆̆ında Çocuk Suçluluğu ve Nedenleri. Yüksek Lisans Tezi, Kırıkkale Üniversitesi Sosyal Bilimler Enstitüsü. Kırıkale.

Beyazıt, U. (2015). Çocuk İstismarı Konusunda Türkiye'de Yapılan Lisansüstü Tezlerin İncelenmesi. Hacettepe University Faculty of Health Sciences Journal, 1(1).

Çavuş, S. (2019). Ortaokul Öğrencilerinin Çocuk Hakları Kavramına İlişkin Bilişsel Yapılarının İncelenmesi. Yüksek Lisans Tezi, Necmettin Erbakan Üniversitesi, Eğitim Bilimleri Enstitüsü. Konya.

Çelik, C. (2005). Çocuk Kavramı ve Medeni Hukuk Açısından Çocuk Haklarının Tarihi Gelişimi. E akademi Dergisi, Sayı 36

Çetinkaya, N. (1998). Öğretmen Ve Öğrencilerin Çocuk Haklarına Bakışlarının Değerlendirilmesi. Yüksek lisans tezi, Marmara Üniversitesi, İstanbul.

Doğan, İ. (2000). Akıllı küçük. İstanbul: Sistem Yayıncılık.

Durgut, A. (2014). 2005 Sosyal Bilgiler Dersi Öğretim Programlarının Çocuk Hakları Açısından İncelenmesi. Yüksek Lisans Tezi, Dumlupınar Üniversitesi, Eğitim Bilimleri Enstitüsü. Kütahya.

Dündar, H. ve Hareket E. (2017). Türkiye'de Çocuk Hakları Bağlamında Yapılan Lisansüstü Tezlerin Araştırma Eğilimlerinin İncelenmesi. MANAS Sosyal Araştırmalar Dergisi (MANAS Journal of Social Studies) Cilt: 6 Sayı: 1, s.77-94.

Erbay, E, (2010), Çocuk hakları ve Türkiye'de Çocuk İş̧iliği Sorunu. Birleşmiş Milletler Çocuk Haklarına Dair Sözleşme'nin 20. Yılında Türkiye'de Çocuk Hakları. (Ed. Hakan Acar ve Arzu İçağasıŏ̆lu Çoban), Ankara: Maya Akademi.

Erbay, E. (2012). Türkiye'de Çocuk Haklarını Tanıtma, Yaygınlaştırma ve İzlemeye Yönelik Uygulamaların Eleştirel Analizi ve Bir Model Önerisi. Toplum ve Sosyal Hizmet Dergisi, Cilt 23, Sayı 2, s.47-74.

Erbay, E. (2013). Çocukların Katılım Hakkı Üzerine Bir Türkiye Değerlendirmesi. İnsan ve Toplum Bilimleri Araştırmaları Dergisi, Cilt.2, Sayı: 1, s.38-54.

Erkan, I. (2018). Türkiye'de Çocuk İstismarı Konusunda Yayımlanan Lisansüstü Tezlerinin Adli Bilimler Açısından Değerlendirilmesi. ACU Sağlık Bilimleri Dergisi, 9(4): $\quad$ s. 410-413. https://doi.org/10.31067/0.2018.49.

Franklin, B. (1993). Çocuk Hakları. çev. Alev Türker. İstanbul: Ayrıntı Yayınları. 
Franklin, B. (1996). The handbook of children's rights. London and Newyork: Rovkledge.

Hançer, G. (2019). Çocuk Hakları ve Çocuk İstismarı Konusunda Sosyal Bilgiler Öğretmen Adaylarının Görüşleri. Yüksek Lisans Tezi, Kastamonu Üniversitesi Sosyal Bilimler Enstitüsü. Kastamonu.

Hodgkin, R., \& Newell, P. (1998). Implementation handbook for the conventation on the Rights of the child. Newyork: UNICEF.

İnan, A. N. (1968). Çocuk Hakları Beyannamesi İlkeleri Türk Hukuk Sistemine Etkisi. Ankara (http://dergiler.ankara.edu.tr/dergiler/40/481/5648.pdf) 11.7.2020 tarihinde erişilmiştir.

İnan, M. R. (1970). İnsan Hakları Eğitim ve Kültür Çocuk Hakları. Ankara: Ankara Üniversitesi Basımevi.

Kadan, G. (2019). Çocuk Haklarına Yönelik Nitel Araştırma Deseninde Yapılan Lisansüstü Tezlerin İncelenmesi. Eurasian Journal Of Health Sctences, (2): s.88-98.

Kalender, B. (2018). Hayat Bilgisi Dersi Öğretim Programlarının Çocuk Hakları Sözleşmesinin Eğitim Hedefleri Maddesi Açısından İncelenmesi: Tarihsel Bir Analiz. Yüksek Lisans Tezi, Gaziantep Üniversitesi, Eğitim Bilimleri Enstitüsü. Gaziantep.

Karasar, N. (2012). Bilimsel Araştırma Yöntemi. Ankara: Nobel Yayıncılık.

Kardeş, S., Banko, Ç., Eren, S., Antakyalığlu, Ş. (2017). Okul Öncesi Öğretmen Adaylarının Çocuk Haklarına İlişkin Görüşleri. Akademik Sosyal Araştırmalar Dergisi, Sayı: 54, s. 469-481.

Kaya, Ö. S. (2011). Öğretmen Adaylarının Çocuk Hakları İle İlgili Görüşleri. Yüksek Lisans Tezi, Afyon Kocatepe Üniversitesi, Sosyal Bilimler Enstitüsü. Afyonkarahisar.

Koran, N. (2015). Öğretmenlere Yönelik Çocuk Hakları ve Hak İhlalleri Eğitiminin Değerlendirilmesi Üzerine Nitel Bir Çalışma. Hacettepe University Faculty of Health Sciences Journal, Vol:1, s.542-557.

Merey, Z. (2012). Türkiye ve ABD'deki Sosyal Bilgiler Ders Kitaplarında Çocukların Katılım Haklarına Yer Verilme Düzeyinin Karşılaştırılması. Doktora Tezi, Gazi Üniversitesi, Eğitim Bilimleri Enstitüsü. Ankara.

Merriam, S. B. (2013). Nitel Araştırma Desen ve Uygulama İçin Bir Rehber. Çev. Ed. Turan, S. Ankara: Nobel.

Moroğlu, N. (2003). Türkiye'de ve Dünya'da Çocuk Hakları. İstanbul: Alman Liseliler Kültür ve Eğitim Vakfı Yay.

Müftü, G. (2013). Bir Tarihçe: Çocukların Hakları Ve Birleşmiş Milletler Çocuk Haklarına Dair Sözleşme. 22 Haziran 2020 tarihinde http://www.cocukhakları izleme.org adresinden erişilmiştir.

Polat, O. (1997). Çocuk Hakları Nedir? İstanbul: Analiz Yayınları

Polat, Ö. (2015). “İnsan Hakları, Çocuk Hakları ve Eğitimi”. Eğgitim Bilimine Giriş. ed. Ayla Oktay. Ankara: Pegem Akademi Yay. 95-123.

Smidt, S. (2006). The Developing Child in the 21st Century. London and Newyork: Routledge.

Şallı, D. (2017). Okul Öncesi Öğretmenlerinin Çocuk Hakları İle İlgili Görüşleri. Eğitim ve Öğretim Araştırmaları Dergisi, Cilt: 6 Sayı: 2, s.80-87.

Taşkın, A. (2019). Çocuk Hakları Konusunda Ebeveyn Tutumları İle Ortaokul Öğrencilerinin Farkındalık Düzeyleri Arasındaki İlişkinin İncelenmesi. Yüksek Lisans Tezi, Giresun Üniversitesi, Sosyal Bilimler Enstitüsü. Giresun.

Tezgel, R. (2008). Yeni İlköğretim Programlarında İnsan Hakları Vatandaşlık ve Kentlilik Eğitimi, Ankara: Araştırma Yayınları. 
Tiftikçi, M. Ş. (2018). Sosyal Bilgiler Beşinci Sınıf Öğrencilerinin Çocuk Hakları Farkındalığına İlişkin Görüşleri. Yüksek Lisans Tezi, Çukurova Üniversitesi, Sosyal Bilimler Enstitüsü. Adana.

Torun, F. (2011). Çocuk Hakları Öğretiminde Oyun Yönteminin Başarıya, Kahııllğa ve Tutuma Etkisi. Yüksek Lisans Tezi, Adıyaman Üniversitesi, Sosyal Bilimler Enstitüsü. Adıyaman.

Trawick-Smith, J. (2014). Çocuk gelişimi kuramları.(M. Buldu, Çev.). İçinde: Erken çocukluk döneminde gelişim. B. Akman (Çev. Ed.).Ankara: Nobel Yayıncıllk. (Early Childhood Development, 5th. Edition. 2010. New Jersey: Pearson).

Turanlı, K. (2014). Birleşmiş Milletler Çocuk Hakları Sözleşmesi Çerçevesinde Çocuğun Ekonomik Sömürüden Korunma Hakkı. Yüksek Lisans Tezi, Anadolu Üniversitesi, Sosyal Bilimler Enstitüsü. Eskişehir.

Uçuş Ş. (2013). Çocuk Hakları Eğitimi Programının Hazırlanması ve Değerlendirilmesi. Doktora tezi, Hacettepe Üniversitesi Eğitim Bilimleri Enstitüsü. Ankara

Uçuş, S. (2009). Çocuk Hakları Sözleşmesinin Illköğretim Programlarındaki Yeri Ve Sözleşmeye Yönelik Öğretmenlerin ve Okul Yöneticilerin Görüşleri, Yüksek Lisans Tezi, Hacettepe Üniversitesi Sosyal Bilimler Enstitüsü, Ankara.

Yapıcı, Ş., \& Yapıcı M. (2004). Bir değer olarak çocukluk. Bilim, Eğitim ve Düşünce Dergisi, 4 (4).

Yıldırım, A. ve Şimşek, H. (2013). Sosyal Bilimlerde Nitel Araştırma Yöntemleri, Ankara: Seçkin Yayınları.

Yörükoğlu, A. (1992). Değişen Toplumda Aile ve Çocuk. 4. Baskı. İstanbul: Özgür Yayınları. 